\title{
ТРАНСПОРТНА ІНФРАСТРУКТУРА ЯК ОБ'ЄКТ ДЕРЖАВНОГО РЕГУЛЮВАННЯ
}

\section{Дмитрісва О.І., канд. екон. наук, доцент \\ Харківський національний автомобільно-дорожній університет}

Постановка проблеми. Транспортна інфраструктура відіграє важливу роль у функціонуванні та розвитку країни, забезпечує зв'язок виробництва та споживання, підтримує рух товарно-матеріальних потоків і робочої сили, задовольняє потреби населення в перевезеннях. Транспортна інфраструктура має забезпечувати своєчасне й ефективне перевезення пасажирів і вантажів та якісне надання супутніх послуг. Основним завданням державного регулювання у сфері транспорту є створення умов безпечного, якісного й ефективного перевезення пасажирів і вантажів та надання додаткових транспортних послуг.

Проте в умовах глобальної кризи транспорт зустрічається 3 багатьма проблемами, які пов'язані з державним регулюванням транспортної галузі. Сучасний стан інфраструктури і рівень організації перевезень не достатньо відповідають сучасним вимогам суспільства та стандартам якості, які висуваються до транспортних послуг.

Аналіз останніх досліджень і публікацій. Транспортна інфраструктура як економічна категорія достатньо вивчена. Функціонування транспортної інфраструктури та ii значення для економіки вивчали такі вітчизняні та зарубіжні науковці як Н. Іксарова, С. Максимова, І. Заблодська. Проблеми та питання, що пов'язані з державним регулюванням в галузі транспорту, досить актуальні та досліджувалися наступними авторами: I. Кузнецова, Н. Троцька, В. Авер'янов, Ю. Старилов.

Всі указані автори розглядають державне регулювання у сфері транспорту з різних аспектів, але не досліджували транспортну інфраструктуру як об'єкт державного регулювання.

Невирішені складові загальної проблеми. 3 огляду на зазначене, на сьогодні невирішеними залишаються питання формування транспортної інфраструктури як об'єкта державного регулювання та обгрунтування його складових.

Формулювання цілей статі. Метою статті $є$ встановлення складу та структури об’єкта при державному регулюванні розвитку транспортної інфраструктури.

Виклад основного матеріалу дослідження. Методологічною основою визначення транспортної інфраструктури як об'єкту державного регулювання $\epsilon$ системний підхід.

Процес формування об'єкту регулювання пропонується досліджувати за допомогою алгоритму, що запропонований у роботі [1], де представлено процес формування об’єкта управління при дослідженні систем управління. 
Пропонується використовувати цей алгоритм, оскільки державне управління та державне регулювання є формами реалізації виконавчої влади, основним призначенням яких $є$ забезпечення практичного виконання законів. Основна відмінність між державним управлінням і державним регулюванням полягає у тому, реалізацію яких інтересів вони забезпечують: державне управління здійснюється у сферах, де необхідним $є$ забезпечення першочергової реалізації публічних інтересів, а державне регулювання - у сферах, де необхідно досягти певного балансу публічних i приватних інтересів [2].

У відповідності до запропонованого алгоритму на першому етапі визначається інформація про об’єкт і можливості суб'єкту.

Державне регулювання - це вид діяльності держави, яка полягає у впорядкуванні діяльності учасників суспільних відносин з метою забезпечення iii відповідності вимогам закону та досягнення бажаного балансу публічних i приватних інтересів [2].

Суб’єктом державного регулювання виступають законодавчі та виконавчі органи держави, галузі, відомчі територіальні органи управління, органи управління підприємствами. Об’єкт управління - діяльність людини, а також різноманітні економічні відносини.

Керований вплив представлено створенням умов, за яких забезпечується виконання нормативно-правових актів: впорядкування, налагодження, визначення напрямків розвитку, підкорення певному порядку, встановлення вірної взаємодії, створення умов нормальної роботи. Державне регулювання передбачає встановлення певних стандартів, нормативів, лімітів, квот, тарифів тощо, дотримання яких є обов'язковим для учасників суспільних відносин i осіб, що здійснюють відповідну діяльність.

Суб'єктами державного регулювання розвитку транспортної інфраструктури в Україні $є$ : на загальнодержавному рівні - Міністерство інфраструктури України, яке відповідає за розвиток транспортно-дорожнього комплексу, координує роботу об'єднань, підприємств, установ та організацій автомобільного, авіаційного, залізничного, морського і річкового транспорту, шляхового господарства; на регіональному рівні - комісії з координації роботи транспорту, створені органами місцевої влади та самоврядування.

У загальному вигляді об'єктом державного регулювання розвитку транспортної інфраструктури є транспортна система України, що включає в себе: транспорт загального користування (залізничний, морський, річковий, автомобільний, авіаційний, міський, метрополітен); промисловий залізничний і відомчий транспорт; трубопровідний транспорт; шляхи сполучення загального користування.

Відповідно до чинного законодавства України основними завданнями державного регулювання в галузі транспорту є:

- своєчасне, повне й якісне задоволення потреб населення і суспільного виробництва в перевезеннях;

- захист прав громадян під час транспортного обслуговування; 
- безпечне функціонування транспорту;

- додержання потрібних темпів $\mathrm{i}$ пропорцій розвитку національної транспортної системи;

- захист економічних інтересів України, законних інтересів підприємств та організацій транспорту і споживачів транспортних послуг;

- створення однакових умов для розвитку господарської діяльності підприємств транспорту;

- обмеження монополізму та розвиток конкуренції;

- координація роботи різних видів транспорту;

- ліцензування окремих видів діяльності в галузі транспорту;

- охорона довкілля від шкідливого впливу транспорту.

Далі при формуванні об'єкту державного регулювання необхідно визначити його сутність і зміст. Основні підходи до визначення терміну «транспортна інфраструктура» представлено у табл. 1.

Таблиия 1

\section{Визначення поняття «транспортна інфраструктура»}

\begin{tabular}{|c|l|}
\hline Автор, джерело & \multicolumn{1}{|c|}{ Визначення терміну } \\
\hline 1 & \multicolumn{1}{|c|}{2} \\
\hline $\begin{array}{c}\text { Постанова } \\
\text { КМУ } \\
{[3]}\end{array}$ & $\begin{array}{l}\text { Сукупність споруд, системи мережі сполучень, усіх видів транспорту, які } \\
\text { задовольняють потреби населення та виробництва у перевезеннях } \\
\text { пасажирів і вантажів. }\end{array}$ \\
\hline $\begin{array}{c}\text { Соколова О. } \\
\text { [4] }\end{array}$ & $\begin{array}{l}\text { Сукупність транспортних шляхів та пунктів усіх видів транспорту й } \\
\text { допоміжного обладнання, спрямованого на безпосереднє обслуговування } \\
\text { шляхів та транспортних пунктів. }\end{array}$ \\
\hline Потєєва М. & $\begin{array}{l}\text { Сукупність матеріальних, кадрових, організаційних, фінансово- } \\
\text { економічних і нормативно-правових умов, які сформовані в країні з метою } \\
\text { забезпечення сталого та якісного перевезення пасажирів і доставки } \\
\text { вантажів в усіх сферах суспільного відтворювального процесу. }\end{array}$ \\
\hline Пікулик О. & $\begin{array}{l}\text { Сукупність транспортних комунікацій, об’єків з обслуговування } \\
\text { п6] }\end{array}$ \\
$\begin{array}{l}\text { пасажирських і вантажнихперевезень, об'єктів технічного обслуговування } \\
\text { та ремонту, які забезпечують умови для надання транспортних послуг, } \\
\text { тобто переміщення вантажів і пасажирів. }\end{array}$ \\
\hline Ткаченко Н. \\
Елементи загальної інфраструктури (будівлі, споруди, пристрої), що \\
забезпечують функціонування та експлуатацію різних видів транспорту. \\
Без такої матеріальної бази транспортування вантажів є або неможливим, \\
або економічно недоцільним.
\end{tabular}


Продовження таблийі 1

\begin{tabular}{|c|c|}
\hline 1 & 2 \\
\hline $\begin{array}{c}\text { Заблодська I. } \\
{[10]}\end{array}$ & $\begin{array}{l}\text { Складова транспортної системи регіону, яку доцільно розглядати як } \\
\text { сукупність транспортних шляхів, вузлів, об'єктів } 3 \text { обслуговування } \\
\text { пасажирських і вантажних перевезень, об'єктів технічного обслуговування } \\
\text { та ремонту, які забезпечують функціонування всіх видів транспорту у } \\
\text { складі транспортної системи регіону. }\end{array}$ \\
\hline $\begin{array}{c}\text { Іксарова Н. } \\
{[11]}\end{array}$ & $\begin{array}{l}\text { До складу даного поняття належать морський, річковий, автомобільний, } \\
\text { залізничний, повітряний і трубопровідний транспорт із відповідними } \\
\text { об’єктами - портами, дорогами, аеропортами, вокзалами, складськими } \\
\text { приміщеннями та іншими допоміжними об'єктами. }\end{array}$ \\
\hline $\begin{array}{c}\text { Жовтяк Г. } \\
\text { [12] }\end{array}$ & $\begin{array}{l}\text { Транспортна система всіх видів транспорту з усіма складовими їх } \\
\text { частинами та ланками, а також іншими обслуговуючими частинами } \\
\text { інфраструктури народного господарства, що працюють у сфері } \\
\text { переміщення вантажів і людей. }\end{array}$ \\
\hline
\end{tabular}

Як бачимо 3 наведених визначень, автори по-різному підходять до терміну «транспортна інфраструктура». На сьогодні немає єдиного підходу до визначення вказаного поняття в науковій літературі - в основному розбіжність між науковцями полягає в дискусії навколо включення в поняття «транспортна інфраструктура» рухомого складу, підприємств, що здійснюють перевезення пасажирів і вантажів, постачальницьких підприємств, галузевих закладів освіти тощо. Разом 3 тим, відповідно до статті 21 Закону України «Про транспорт», де надається визначення поняттю «єдина транспортна система України», до якої входять всі види транспорту та шляхів сполучення, зазначено, що єдина транспортна система повинна відповідати вимогам суспільного виробництва та національної безпеки, мати розгалужену інфраструктуру для надання всього комплексу транспортних послуг, у тому числі для складування та технологічної підготовки вантажів до транспортування, забезпечувати зовнішньоекономічні зв'язки України. Таким чином, транспортна інфраструктура $\epsilon$ складовою частиною єдиної транспортної системи та покликана забезпечити умови іiі функціонування, тому не включає в себе рухомий склад, підприємства, що здійснюють перевезення пасажирів і вантажів.

Таким чином до складу транспортної інфраструктури відносяться: залізничні шляхи, автомобільні дороги різного рівня технічного оснащення, водні шляхи, повітряні траси, станції, мости, шляхопроводи, тунелі, морські та річкові порти, аеропорти, локомотивні та вагонні депо, підприємства транспортного машинобудування та ремонту.

На рис. 1 наведено склад і структуру транспортної інфраструктури. 
Мережа шляхів

Автомобільні шляхи;

Залізничні (рейкові) шляхи;

Водні шляхи;

Повітряні коридори;

Трубопроводи

Об'єкти транспортного сервісу

Вокзали, автостанції, аеропорти, порти, термінали, метрополітен;

Об'єкти дорожнього сервісу;

Логістичні центри;

Станції технічного обслуговування, автозаправні станції

\section{Рис. 1. Складові транспортної інфраструктури}

Транспортна інфраструктура - це економічно збалансована сукупність елементів загальної інфраструктури (мереж шляхів та об'єктів транспортного сервісу), що забезпечує функціонування та експлуатацію різних видів транспорту (морський, річковий, автомобільний, залізничний, повітряний, міський, трубопровідний).

На наступному етапі необхідно чітко сформулювати цілі та задачі державного регулювання розвитку транспортної інфраструктури. Мета - це бажаний стан об'єкту або бажані результати його діяльності.

Основною метою функціонування транспортної інфраструктури $\epsilon$ забезпечення потреб населення та господарства в усіх видах перевезень.

На наступному етапі необхідно встановити взаємозв'язок об'єкта регулювання та середовища. Чіткої межи між зовнішнім і внутрішнім середовищем, в якому функціонує об'єкт, не існує, але $\epsilon$ тісний взаємозв'язок між ними. До внутрішніх чинників можна віднести: ресурси, організаційну структуру та структуру управління, систему управління, персонал і культуру.

Зовнішні чинники, що впливають на функціонування транспортної інфраструктури, представлені факторами макро- та мікросередовища. До факторів макросередовища відносяться: політико-правові; економічні; соціальні; технологічні; природні. До факторів мікросередовища відносяться: постачальники; споживачі; конкуренти; посередники; контактні аудиторії.

На основі вищевказаних елементів характер взаємодії транспортної інфраструктури як об'єкту державного регулювання з середовищем можна представити у вигляді моделі (рис. 2). 


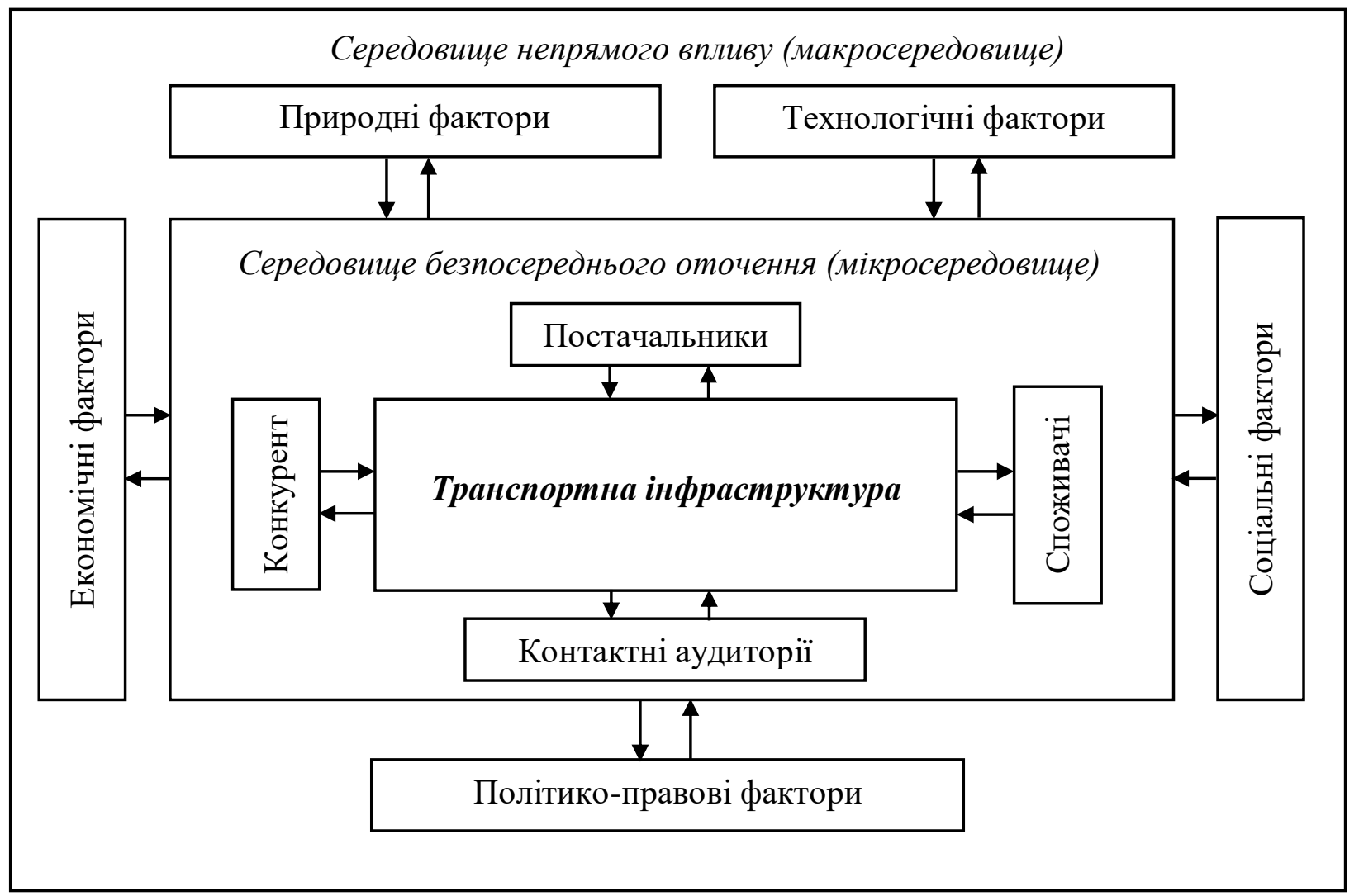

\section{Рис. 2. Взаємодія транспортної інфраструктури як об'скта державного регулювання 3 середовищем}

Наступний етап формування об'єкта регулювання передбачає побудову моделі, що містить елементи об'єкта, суб'єкта та зв'язки між ними.

Згідно із системно-кібернетичним підходом [13] система управління як форма реального втілення певних управлінських впливів складається із двох взаємодіючих підсистем: керуючої - суб'єкт управління (формує управлінський вплив); керованої - об'єкт управління (зазнає сформованих впливів). У кожній без виключення системі управління $\epsilon$ : прямий зв'язок - зв'язок керуючої підсистеми з керованою; протилежний за напрямом дії - зворотний зв'язок (від керованої підсистеми до керуючої). Таким чином, суб'єкт регулювання через канал прямого зв'язку впливає на об'єкт, коригуючи впливи на нього середовища. Це приводить до зміни стану об'єкта регулювання - він змінює свій вплив на середовище.

Процес державного регулювання розвитку транспортної інфраструктури, згідно із системно-кібернетичним підходом, представлено у вигляді моделі (рис. 3).

Оскільки об'єктом регулювання виступає транспортна інфраструктура, то під регулюванням слід розуміти безперервний і цілеспрямований вплив на сукупність елементів транспортної інфраструктури. 


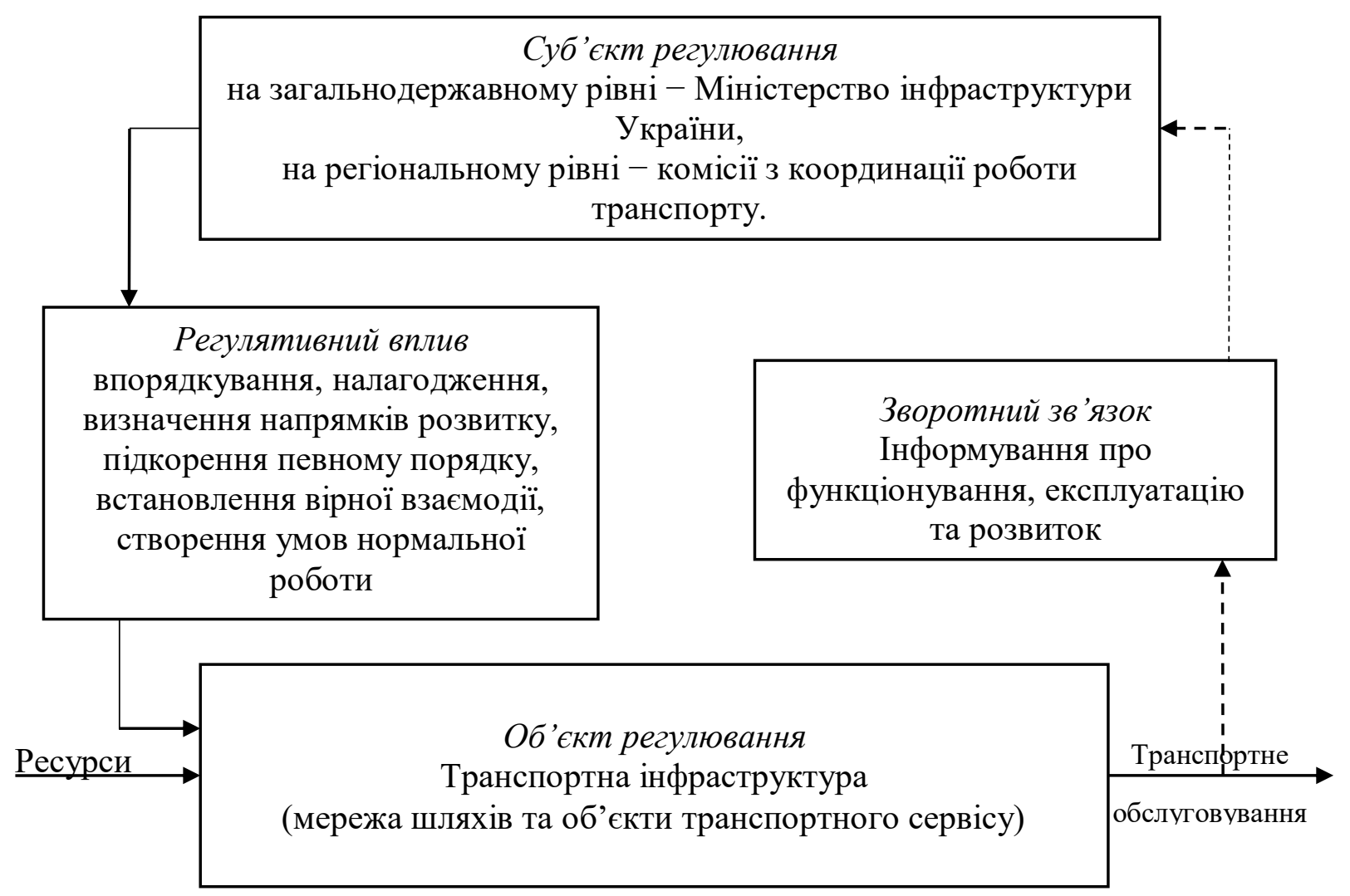

Рис. 3. Загальна схема процесу державного регулювання розвитку транспортної інфраструктури згідно системно-кібернетичного підходу

Висновки. Встановлено склад і структуру об’єкту при державному регулюванні розвитку транспортної інфраструктури: визначено сутність і зміст транспортної інфраструктури; сформульовано цілі та задачі державного регулювання розвитку транспортної інфраструктури; встановлено взаємозв'язок транспортної інфраструктури як об'єкта державного регулювання та середовища; встановлено характер відносин транспортної інфраструктури як об'єкта державного регулювання та середовища; визначено інформаційне забезпечення зв'язків між об'єктом, суб'єктом і завданнями державного регулювання розвитку транспортної інфраструктури. Запропоновано модель державного регулювання розвитку транспортної інфраструктури.

\section{Перелік посилань}

1. Шинкаренко В. Г., Криворучко О. М. Формирование объектов при исследовании систем управления. Економіка транспортного комплексу: $з б$. наук. праць. Харків: ХНАДУ. 2001. Вип. 4. С. 5-11.

2. Дєгтяр О. А. Державне регулювання розвитку соціальної сфери: концептуальні засади та практика: монографія. Харків: С.А.М, 2014. 508 с.

3. Про затвердження Концепції реформування транспортного сектору економіки: Постанова КМУ від 9.11.2000 р. № 1684. URL: http://www.nau.kiev. ua/nau10/ukr/getcnt.php?uid=1049.1530.0\&nobreak (дата звернення: 11.02.2020).

4. Соколова О. С. Проблеми управління логістичною інфраструктурою підприємств. Проблеми системного підходу в економіuі. 2007. Вип. 2. URL: 

11.02.2020).

5. Потеева М. А. Роль транспортной системы в устойчивом развитии экономики Крыма. Культура народов Причерноморья. 2004. № 56. Т. 2. С. 123131.

6. Пікулик О. Б. Пріоритетні напрями розвитку транспортної системи Західного регіону України в умовах європейської інтеграції. Науковий вісник Волинського національного університету ім. Лесі Українки. 2008. № 7. С. 284291.

7. Ткаченко Н. Ю. Транспортна інфраструктура: сутність, функції та роль у забезпеченні економічних процесів. Вісник ДонДУЕТ. Серія: Економічні науки. 2006. № 4(32). С. 56-61.

8. Фастовець О. О. Розвиток транспортної системи з найдавніших часів до початку XX ст. як чинник виникнення туристичної галузі. Туристичнокраєзнавські дослідження. Вип. 4. К.: Держ. п-во «Нац. турист. організація». 2002. C. 418-443.

9. Максимова С. Ю. Инновационные технологии в управлении развитием транспортно-логистической инфраструктуры региона. Инновации в экономике, управлении и образовании: монография. Ставрополь: СИЭУ ФПГТУ, 2009. $357 \mathrm{c.}$

10. Заблодська I. В., Бузько I. Р., Зеленко О. О., Хорошилова I. О. Інфраструктурне забезпечення розвитку транспортної системи регіону: монографія. Сєвєродонецьк: Вид-во СНУ ім. В. Даля, 2016. 193 с.

11. Іксарова Н. О. Транспортна інфраструктура як компонент економічної безпеки України. Економічний простір. 2010. № 36. С. 55-61.

12. Жовтяк Г. А. Теоретико-методичні підходи до визначення поняття «транспортна інфраструктура регіону». Ефективна економіка. 2011. № 11. URL: http://nbuv.gov.ua/UJRN/efek_2011_11_35 (дата звернення: 12.02.2020).

13. Малин А. С., Мухин В. И. Исследование систем управления: учебник для вузов. М.: Изд. дом ГУ ВШЭ, 2005. 400 с.

\section{References}

1. Shinkarenko, V. G., Krivoruchko, O. M. (2001), Forming the objects in the research of management systems [Formirovanie ob"ektov pri issledovanii sistem upravleniya], Economy of transport complex, No 4, P. 5-11.

2. Diehtiar, O. A. (2014), Government regulation of development of the social sphere: conceptual principles and practice: monograph [Derzhavne rehuliuvannia rozvytku sotsialnoi sfery: kontseptualni zasady ta praktyka: monohrafiia], Kharkiv: S.A.M, 508 p.

3. About claim of Conception of reformation of the transport sector of economy: Resolution of KMU from 9.11.2000 No 1684 [Pro zatverdzhennia Kontseptsii reformuvannia transportnoho sektoru ekonomiky: Postanova KMU vid 9.11.2000 r. No 1684], available at: http://www.nau.kiev.ua/nau10/ukr/getcnt.php? uid=1049.1530.0\&nobreak (last accessed 11.02.2020). 
4. Sokolova, O. Ye. (2007), Problems of management of the logistic infrastructure of enterprises [Problemy upravlinnia lohistychnoiu infrastrukturoiu pidpryiemstv], Problems of system approach in economy, No 2, available at: $\mathrm{http} /$ /www.nbuv.gov.ua/ejournals/PSPE/ 2007-2/index.html (last accessed 11.02.2020).

5. Poteeva, M. A. (2004), Role of the transport system in sustainable development of economy of Crimea [Rol' transportnoy sistemy $\mathrm{v}$ ustoychivom razvitii ekonomiki Kryma], Culture of peoples of Black sea region, No 56 (2), P. 123131.

6. Pikulyk, O. B. (2008), Priority directions of development of the transport system of the West region of Ukraine in the conditions of european integration [Priorytetni napriamy rozvytku transportnoi systemy Zakhidnoho rehionu Ukrainy $\mathrm{v}$ umovakh yevropeiskoi intehratsii], Scientific herald of the Volyn national university named after Lesia Ukrainka, No 7, P. 284-291.

7. Tkachenko, N. Yu. (2006), Transport infrastructure: essence, functions and role in providing the economic processes [Transportna infrastruktura: sutnist, funktsii ta rol u zabezpechenni ekonomichnykh protsesiv], Herald of the DonDUET. Series: Economic sciences, No 4 (32), P. 56-61.

8. Fastovets, O. O. (2002), Development of the transport system from the oldest times to beginning of XX century as a factor of occurrence of tourist industry [Rozvytok transportnoi systemy $\mathrm{z}$ naidavnishykh chasiv do pochatku XX st. yak chynnyk vynyknennia turystychnoi haluzi], Tourism and local history research, No 4, P. 418-443.

9. Maksimova, S. Yu. (2009), Innovative technologies in management of development of the transport-logistical infrastructure of region. Innovations in economy, management and education: monograph [Innovatsionnye tekhnologii $v$ upravlenii razvitiem transportno-logisticheskoy infrastruktury regiona. Innovatsii $v$ ekonomike, upravlenii i obrazovanii: monografiya], Stavropol: SIEU FPGTU, 357 p.

10. Zablodska, I. V., Buzko, I. R., Zelenko, O. O., Khoroshylova, I. O. (2016), Infrastructural providing the development of transport system of region: monograph [Infrastrukturne zabezpechennia rozvytku transportnoi systemy rehionu: monohrafiia], Severodonetsk: Publishing House of SNU them. V. Dalia, 193 p.

11. Iksarova, N. O. (2010), Transport infrastructure as a component of economic security of Ukraine [Transportna infrastruktura yak komponent ekonomichnoi bezpeky Ukrainy], Economic space, No 36, P. 55-61.

12. Zhovtiak, H. A. (2011), Theoretical and methodical approaches to determination of concept "transport infrastructure of region" [Teoretyko-metodychni pidkhody do vyznachennia poniattia «transportna infrastruktura rehionu»], Effective economy, No 11, available at: http://nbuv.gov.ua/ UJRN/efek_2011_11_35 (last accessed 12.02.2020)

13. Malin, A. S., Mukhin, V. I. (2005), Research of management systems: textbook for high schools [Issledovanie sistem upravleniya: uchebnik dlya vuzov], M.: Publishing. house of the Higher School of Economics, 400 p. 


\section{РЕФЕРАТИ РЕФЕРАТЫ ABSTRACTS}

\section{УДК 656.01; JEL Classification: R40}

\section{ДМИтрієва О.І. ТРАНСПОРТНА ІНФРАСТРУКТУРА ЯК ОБ'ЄКТ ДЕРЖАВНОГО РЕГУЛЮВАННЯ}

Мета дослідження полягає у встановленні складу та структури об'єкта при державному регулюванні розвитку транспортної інфраструктури. Методика дослідження. Для досягнення поставленої мети у науковій роботі були використані такі загальнонаукові та спеціальні методи і прийоми дослідження: методи узагальнення та абстрагування - для уточнення сутності транспортної інфраструктури, теоретичних засад та інструментарію державного регулювання розвитку транспортної інфраструктури; системного та комплексного підходу - для визначення складових транспортної інфраструктури. Результати дослідження. У статті проведений аналіз наукової літератури дав змогу автору визначити найбільш комплексну та змістовну дефініцію «транспортна інфраструктура»; досліджено складові транспортної інфраструктури. Визначено основні завдання державного регулювання на транспорті. Встановлено склад і структуру об'єкту при державному регулюванні розвитку транспортної інфраструктури: визначено сутність і зміст транспортної інфраструктури; сформульовано цілі та задачі державного регулювання розвитку транспортної інфраструктури; встановлено взаємозв'язок транспортної інфраструктури як об'єкта державного регулювання та середовища; встановлено характер відносин транспортної інфраструктури як об'єкта державного регулювання та середовища; визначено інформаційне забезпечення зв'язків між об'єктом, суб'єктом і завданнями державного регулювання розвитку транспортної інфраструктури. Запропоновано модель державного регулювання розвитку транспортної інфраструктури. Наукова новизна. Полягає у визначенні складу та структури транспортної інфраструктури. Розроблено модель об'єкту при державному регулюванні розвитку транспортної інфраструктури, яка сформована на основі ідентифікації та розмежування ії складових. Практичне значення отриманих результатів. Модель об'єкта при державному регулюванні розвитку транспортної інфраструктури, яка сформована на основі розмежування іiі складових i визначення основних характеристик, $\epsilon$ підгрунтям для упорядкування управлінських процедур і застосування найбільш доцільних та ефективних методів їх реалізації.

Ключові слова: транспортна інфраструктура; державне регулювання; об'єкт державного регулювання; зовнішні та внутрішні чинники; системний підхід.

УДК 656.01; JEL Classification: R40

ДМИТРИеВа О.И. ТРАНСПОРТНАЯ ИНФРАСТРУКТУРА КАК ОБЪЕКТ ГОСУДАРСТВЕННОГО РЕГУЛИРОВАНИЯ

Цель исследования заключается в установлении состава и структуры объекта при государственном регулировании развития транспортной 
инфраструктуры. Методика исследования. Для достижения поставленной цели в научной работе были использованы такие общенаучные и специальные методы и приемы исследования: методы обобщения и абстрагирования - для уточнения сущности транспортной инфраструктуры, теоретических основ и инструментария государственного регулирования развития транспортной инфраструктуры; системного и комплексного подхода - для определения составляющих транспортной инфраструктуры. Результаты исследования. В статье проведенный анализ научной литературы дал возможность автору определить наиболее комплексную и содержательную дефиницию «транспортная инфраструктура»; исследовано составляющие транспортной инфраструктуры. Определено основные задания государственного регулирования на транспорте. Установлено состав и структуру объекта при государственном регулировании развития транспортной инфраструктуры: определено сущность и содержание транспортной инфраструктуры; сформулировано цели и задачи государственного регулирования развития транспортной инфраструктуры; установлено взаимосвязь транспортной инфраструктуры как объекта государственного регулирования и среды; установлено характер отношений транспортной инфраструктуры как объекта государственного регулирования и среды; определено информационное обеспечение связей между объектом, субъектом и заданиями государственного регулирования развития транспортной инфраструктуры. Предложено модель государственного регулирования развития транспортной инфраструктуры. Научная новизна. Заключается в определении состава и структуры транспортной инфраструктуры. Разработано модель объекта при государственном регулировании развития транспортной инфраструктуры, которая сформирована на основе идентификации и разграничения ее составляющих. Практическое значение полученных результатов. Модель объекта при государственном регулировании развития транспортной инфраструктуры, которая сформирована на основе разграничения ее составляющих и определения основных характеристик, является основой для упорядочивания управленческих процедур и применения наиболее целесообразных и эффективных методов их реализации.

Ключевые слова: транспортная инфраструктура; государственное регулирование; объект государственного регулирования; внешние и внутренние факторы; системный подход.

\section{UDC 656.01; JEL Classification: R40}

\section{Dmytriieva O.I. TRANSPORT INFRASTRUCTURE AS AN OBJECT OF THE STATE REGULATION}

The aim of research is determining the composition and structure of object in the state regulation of transport infrastructure development. Methodology of research. In order to achieve target goal the following scientific and special methods and research methods were used in scientific work: methods of generalization and abstraction - for clarify the essence of transport infrastructure, theoretical principles and instruments of the state regulation of transport infrastructure development; 
systematic and comprehensive approach - for defining the transport infrastructure components. Findings. In the article the analysis of scientific literature allowed the author to determine the most comprehensive and meaningful definition "transport infrastructure"; transport infrastructure components are investigated. The main tasks of the state regulation in transport are determined. The composition and structure of object in the state regulation of transport infrastructure development are determined: the nature and content of the transport infrastructure are determined; the goals and objectives of the state regulation of transport infrastructure development are formulated; the interconnection between the transport infrastructure as an object of state regulation and the environment is established; the nature of the relations between the transport infrastructure as an object of state regulation and the environment is established; the information support of the relations between an object, a subject and tasks of the state regulation of transport infrastructure development is defined. The model of the state regulation of transport infrastructure development is proposed. Originality. The composition and structure of transport infrastructure are defined. The model of object in the state regulation of development of the transport infrastructure is developed, which is formed on the basis of identification and delimitation of its components. Practical value. The model of object in the state regulation of transport infrastructure development, which is formed on the basis of delimitation of its components and the definition of the main characteristics, is the basis for ordering the management procedures and using the most appropriate and effective methods of their implementation.

Key words: transport infrastructure; state regulation; object of the state regulation; external and internal factors; systematic approach.

\section{Відомості про авторів / Сведения об авторах / About the Authors}

Дмитрієва Оксана Іллівна - кандидат економічних наук, доцент, Харківський національний автомобільно-дорожній університет, доцент кафедри управління та адміністрування, м. Харків, Україна; е-mail: oksanahnadu@gmail.com; ORCID: 0000-0001-9314-350X. Моб. (063) 353-79-98.

Дмитриева Оксана Ильинична - кандидат экономических наук, доцент, Харьковский национальный автомобильно-дорожный университет, доцент кафедры управления и администрирования, г. Харьков, Украина.

Dmytriieva Oksana - $\mathrm{PhD}$ in Economics, Associate Professor, Kharkiv National Automobile and Highway University, Associate Professor of the Department of Management and Administration, Kharkiv, Ukraine. 